\title{
Possibilities and the parallel meanings of factual and counterfactual conditionals
}

\author{
Orlando Espino $^{1}$ - Ruth M. J. Byrne ${ }^{2}$ P. N. Johnson-Laird ${ }^{3,4}$ \\ Published online: 3 June 2020 \\ (C) The Psychonomic Society, Inc. 2020
}

\begin{abstract}
The mental model theory postulates that the meanings of conditionals are based on possibilities. Indicative conditionals-such as "If he is injured tomorrow, then he will take some leave"-have a factual interpretation that can be paraphrased as It is possible, and remains so, that he is injured tomorrow, and in that case certain that he takes some leave. Subjunctive conditionals, such as, "If he were injured tomorrow, then he would take some leave," have a prefactual interpretation that has the same paraphrase. But when context makes clear that his injury will not occur, the subjunctive has a counterfactual paraphrase, with the first clause: It was once possible, but does not remain so, that he will be injured tomorrow. Three experiments corroborated these predictions for participants' selections of paraphrases in their native Spanish, for epistemic and deontic conditionals, for those referring to past and to future events, and for those with then clauses referring to what may or must happen. These results are contrary to normal modal logics. They are also contrary to theories based on probabilities, which are inapplicable to deontic conditionals, such as, "If you have a ticket, then you must enter the show."
\end{abstract}

Keywords Conditionals $\cdot$ Conditional probabilities $\cdot$ Counterfactuals $\cdot$ Mental models $\cdot$ Probabilities $\cdot$ Semantics

Conditionals are a notorious cause of controversy in cognitive science. They are the propositions that can be expressed in English using the grammatical form "If A, then C," where both $\mathrm{A}$ and $\mathrm{C}$ are clauses. At the center of disagreement is their meaning (Nickerson, 2015). The consequences of the disagreement concern the truth or falsity of conditional assertions, their probability whether qualitative or numerical (e.g., "highly probable" vs. "70\% probable"), their inferential consequences, and their mental representations. Philosophers, linguists, and psychologists have explored four principal approaches to their meaning. The truth-functional approach defines their meaning as a function of the truth values - true or

Orlando Espino

oespinom@ull.edu.es

1 Departamento de Psicología Cognitiva, Universidad de la Laguna, Campus de Guajara, 38205 Tenerife, Spain

2 School of Psychology and Institute of Neuroscience, Trinity College Dublin, University of Dublin, Dublin, Ireland

3 Emeritus, Department of Psychology, Princeton University, Princeton, NJ, USA

4 Visiting scholar, Department of Psychology, New York University, New York, NY, USA false - of the clauses they connect. The possible-worlds approach defines their meaning in terms of an infinite set of hypothetical worlds, which include the real one, and which each fix the truth values of all propositions about it. The probabilistic approach defines their meaning in terms of the conditional probabilities of their then clauses given their if clauses. And the model approach defines their meanings in terms of possibilities, which are represented in small mental models of the situation and finite alternatives. The article describes each of these approaches. They are neither exhaustive nor mutually exclusive, and, as we show, at least one theory is based both on truth functions and possible worlds. Indeed, the aim of the present article is to make progress towards a unified theory of their meaning based on recent developments in the model theory, on evidence about probabilities, and on an account of various sorts of possibility.

In what follows, we describe a taxonomy of conditionals, and each of the principal theories of their meanings. Unlike other approaches, the model theory predicts different sorts of paraphrases concerning possibilities that naïve individualsthose who have not studied logic or linguistics - should accept for the main sorts of conditionals. We then describe three experiments testing these predictions. Finally, we discuss the implications of the results for each of the main approaches to the meanings of conditionals. 


\section{A taxonomy of conditionals}

Conditionals in English and other Indo-European languages, including Spanish - the language in which we carried out our experiments - can make assertions, pose questions, and give orders. Our focus, as in almost all studies of if in cognitive science, is on assertions, because their meanings can be transformed into those for the other sorts of speech act.

A taxonomy of conditionals is pertinent to our investigations, and it depends on mood, modality, and temporal reference. An assertion in the indicative mood conveys what we refer to as a factual conditional (e.g., "If he speaks Italian, then he will do so in the interview"). However, the mood can instead be subjunctive (e.g., "If he were to speak Italian, then he would do so in the interview"). Subjunctives are open to two interpretations (see, e.g., Johnson-Laird \& Byrne, 2002, p. 653). One interpretation leaves open a factual meaning, and it can be made explicit (e.g., "If he were to speak Italian, which he can do, then he would do so in the interview"). Such conditionals are known as prefactual (e.g., Byrne \& Egan, 2004). The other interpretation is counterfactual, which can also be made explicit (e.g., "If he were to speak Italian, which he can't do, then he would do so in the interview").

Modality concerns possibilities, and three main modalities exist in Indo-European languages (see, e.g., JohnsonLaird \& Ragni, 2019). Epistemic possibilities depend on general knowledge, as in the examples above (e.g., "If the forecast is correct, then it may rain tomorrow"). As we show below, they resemble subjective probabilities. Deontic possibilities concern what is permissible, and they depend on morals, rules, and conventions (e.g., "If you speak Italian, then you must do so in the interview"). In a felicitous context, this speech act can create an obligation for you. Alethic possibilities concern the relations between, say, premises and conclusions, as when the former necessitates the latter (e.g., "If a number is divisible by 4 with no remainder, then it necessarily follows that it is even"). Such conditionals await further investigation, because the present article concerns only epistemic and deontic interpretations. Their then clauses refer to possibilities or to certainties in the case of epistemic conditionals, as in this contrast between "If he speaks Italian, then he may do so in the interview" (a possibility) and "If he speaks Italian, then he will do so in the interview" (a certainty). The analogous contrast for deontic conditionals is between permissions and obligations, as in the contrast between "If you speak Italian, then you can do so in the interview" (a permission) and "If you speak Italian, then you must do so in the interview" (an obligation). Readers might suppose that epistemic possibilities contrast with epistemic necessities, but linguistic analysis shows that they do not. Epistemic necessities make claims about what is necessary for some other case to hold (see Johnson-Laird \& Ragni, 2019; Kratzer, 2012; Lassiter, 2017; White, 1975). For example, "It is necessary that he does the interview" asserts not the certainty of its occurrence but rather its necessity for some other condition, such as for him to get the job. Hence, the theorists cited above argue that epistemic claims are on a scale running from impossibility through possibility to certainty, rather than a binary distinction between possibility and necessity. In contrast, there is debate about whether deontic claims are all or none (see, e.g., Johnson-Laird \& Ragni, 2019) or come in degrees (Malle, 2018). Perhaps one person can be more obligated than another to carry out a particular action, and one action can be more obligatory than another.

The final distinction in the taxonomy concerns the temporality of the events to which conditionals refer in relation to the time of utterance: past, present, or future. Spanish verbs can be in each of these three tenses; English verbs can be only in the past or present tense. But in both languages, cues such as adverbials and the aspect of verbs can distinguish present or future events using the present tense-for example, "If he is speaking English now ..." (present event) or "If he speaks English tomorrow ..." (future event).

But temporal references can be complicated in IndoEuropean languages. They distinguish three sorts of referent: the time of an utterance, the time of the event referred to in it, and a reference time created in another utterance (e.g., Miller \& Johnson-Laird, 1976, Sec. 6.2; Moens \& Steedman, 1988; Reichenbach, 1956). Studies of conditionals, and counterfactuals in particular, have neglected those about future events in comparison with those about the past (for a notable exception, see Schaeken, Schroyens, \& Dieussaert, 2001). So, we made a point of investigating them.

In summary, conditionals can vary in whether they are factual, prefactual, or counterfactual, whether they concern alethic, epistemic, or deontic modalities, and whether they refer to past, present, or future events. These differences need to be taken into account in any general theory of their meaning.

\section{Theories of the meanings of conditionals}

One long-standing view about the meaning of conditional assertions is that it is truth functional - that is, their truth or falsity depends solely on the truth or falsity of their clauses. So, a factual conditional such as "If he speaks Italian tomorrow, then he will do so in the interview" is true in the case that he speaks Italian tomorrow and speaks it in the interview. It is false in the case that he speaks Italian tomorrow and does not speak it in the interview. And it is true in any other case (i.e., he does not speak Italian tomorrow; see, e.g., Jeffrey, 1981). In general, If $A$, then $C$ is false only in the case of $A$ and not $C$, 
and true in any other case. One difficulty with such an account is that it cannot apply to counterfactual conditionals, such as "If she had spoken Italian yesterday, which she didn't, then she would have spoken it in the interview." It cannot be truth functional (Jeffrey, 1981, p. 62). In its truth-functional meaning, a false if clause suffices for a conditional to be true, but this counterfactual conditional, which has a false if clause, could be true or false. It would be false, for example, if she never speaks Italian in interviews. Lewis (1973) therefore argued that factual conditionals are truth functional, whereas counterfactual conditionals have a semantics based on possible worlds. According to his theory, the example above is true provided that in whichever possible world is closest to the real world except that she did speak Italian yesterday, it is also the case that she spoke it in the interview. Another philosophical theory unifies both factual and counterfactual conditionals within a single semantics of possible worlds (Stalnaker, 1968). A conditional If $A$, then $C$ is true in the actual world given that there is a possible world in which $A$ is true, which differs minimally from the actual world, and in which $C$ is true, too.

For some theorists, still another alternative is that the meaning of conditionals is probabilistic (Adams, 1998). According to this conjecture, they mean that their then clauses are probable given that their if clauses hold (i.e., they express a conditional probability; see, e.g., Fugard, Pfeifer, Mayerhofer, \& Kleiter, 2011; Oaksford \& Chater, 2007). A corollary is the well-known equation in which the probability of a conditional is equal to the conditional probability of its then clause given its if clause. The approach has tended to neglect counterfactual conditionals (Over \& Cruz, 2017; but cf. Lucas \& Kemp, 2015). A sensible treatment is that the probability of a counterfactual conditional about a future event is the same as the probability of the corresponding factual conditional when its if clause could still be true or false (Adams, 1975). A version of this idea also takes into account the probabilities of the facts that the counterfactual implies (Elqayam \& Over, 2013).

We come back to the three preceding theories in the General Discussion to assess them in the light of our experimental results. Meanwhile, we turn to a final alternative - the model theory. The model theory postulates that conditional assertions have truth values and that their semantics, as for other sentential connectives, such as disjunctions, are based on possibilities. Mental models are finite representations that simulate the world by embodying the same structural relations, insofar as possible, as those under description. They can therefore underlie not only images but also abstract social relations (see, e.g., Johnson-Laird, 1983, 2006; Johnson-Laird \& Byrne, 1991). They can simulate kinematic sequences of events in time (Khemlani, Mackiewicz, Bucciarelli, \&
Johnson-Laird, 2013). They can contain symbols, too, such as numerals and negation (see Espino \& Byrne, 2018). And a model can represent factual or counterfactual possibilities those that were once possible, but that did not occur. The theory has long postulated that conditionals have models of possibilities (Byrne, 2005; Johnson-Laird \& Byrne, 2002), but it has undergone several recent developments, of which two are pertinent to what follows.

First, the theory postulates that all sentential connectives refer to conjunctions of possibilities that hold in default of knowledge to the contrary (Johnson-Laird, Khemlani, \& Goodwin, 2015; Khemlani, Byrne, \& Johnson-Laird, 2018). Evidence has corroborated the theory for disjunctions (Hinterecker, Knauff, \& Johnson-Laird, 2016). A corollary of default assertions is that they can be withdrawn in the face of knowledge to the contrary, and so the reasoning system is defeasible. In orthodox logic, when a fact contradicts a conclusion, there is no need to withdraw the conclusion: A contradiction validly implies any conclusion whatsoever. As a consequence, logic is "monotonic" in that any additional premise yields only additional conclusions, and never calls for a withdrawal of a conclusion. That is not how naïve individuals react to facts that are inconsistent with their conclusions, and so it is not how the model theory operates, either. It is "nonmonotonic," which means that it does not maintain conclusions in the face of facts that are inconsistent with them (see, e.g., Johnson-Laird et al., 2015).

Second, the theory provides a finite semantics for the different sorts of possibility - epistemic, deontic, and alethic. Their meanings have common roots in the human ability to envisage a small number of models of the exhaustive alternatives in any situation, which can each be realized in an indefinite number of ways (Johnson-Laird \& Ragni, 2019). For example, at the time of this writing, many Americans can conceive of a small number of alternative outcomes to the Democratic primaries. Their models of any such alternatives are equivalent to exhaustive possibilities from which individuals can sample those that are probable, useful, or good (Phillips, Morris, \& Cushman, 2019).

The theory's account of the meanings of conditionals is straightforward. A factual conditional such as "If it rains tomorrow, then the flowers may survive" has a meaning that refers to a conjunction of default epistemic possibilities, and so it can be expressed parsimoniously, such as "It is possible that it rains tomorrow and that the flowers possibly survive." Its first clause has a presupposition yielding a further conjunct that also holds in default of contrary knowledge: ". . . and it is possible that it does not rain tomorrow." Counterfactual conditionals refer to counterfactual possibilities (i.e., ones that were once possible, but that did not occur; Byrne, 2005, 2016; De Brigard \& Parikh, 2019; Johnson-Laird \& Byrne, 2002). Hence, a factual conditional's possibilities map in a systematic way to the counterfactual possibilities for a 
counterfactual conditional, as follows (from Byrne \& Johnson-Laird, 2019):

\begin{tabular}{|c|c|c|c|}
\hline Cases: & Factual: & Counterfactual: & \\
\hline$C$ & $\begin{array}{l}\text { then } C \text { would have } \\
\text { happened }\end{array}$ & & \\
\hline A & $\mathrm{C}$ & Possible & $\begin{array}{c}\text { Possible } \\
\text { once }\end{array}$ \\
\hline A & Not C & Impossible & Impossible \\
\hline Not A & $\mathrm{C}$ & Possible & $\begin{array}{c}\text { Possible } \\
\text { once }\end{array}$ \\
\hline Not A & Not C & Possible & Fact \\
\hline
\end{tabular}

When people know that these possibilities hold for conditionals, they judge them to be true (i.e., without the need for further evidence; Quelhas, Rasga, \& Johnson-Laird, 2017, 2018). Likewise, conditionals prime the appropriate possibilities (Santamaría, Espino, \& Byrne, 2005), and conversely, possibilities prime the appropriate conditionals (Espino, Santamaría, \& Byrne, 2009). In addition, however, both knowledge and the meanings of clauses can modulate conditionals to yield different interpretations (e.g., they can block certain possibilities; e.g., Johnson-Laird \& Byrne, 2002; Quelhas, Johnson-Laird, \& Juhos, 2010). These changes affect both the meanings of conditionals and the inferences that people draw from them.

The counterfactual conditional corresponding to the factual one above is "If it were to rain tomorrow (and it won't), then the flowers might survive." Its meaning can be expressed as "It was once possible, but not any longer, that it rains tomorrow and that the flowers may survive." In sum, according to the model theory, conditionals refer to possibilities, real or counterfactual, that hold in default of knowledge to the contrary. These meanings should run in parallel for epistemic and deontic conditionals, and have systematic relations between factual and counterfactual conditionals. They can be framed for events in the past, present, or future, and their then clauses can, in turn, refer to events that are possible or certain in epistemic interpretations, and permissible or obligatory in deontic interpretations. Our studies concerned paraphrases of conditionals, which the preceding analyses imply. So, individuals given a factual conditional such as "If it is raining, then the streets will be wet" should select as an accurate paraphrase an assertion such as "It is possible, and remains so, that it is raining, and in that case certain that the streets are wet."

Readers may be tempted to assume that the preceding paraphrase is trivial and obviously a valid inference. It can be analyzed in a normal modal logic (see, e.g., Girle, 2009), and a countable infinity of them exist (see, e.g., Johnson-Laird \& Ragni, 2019). Yet, in all of them, the inference of the paraphrase is invalid. Here is a counterexample that establishes this point. Suppose that it is impossible that is raining. It follows that the conjunction of the clauses in the paraphrase above is false because the impossibility of rain contradicts its first clause. But the supposition also implies that it is not raining, and that suffices for the conditional above to be true in all normal modal logics. That is because they embrace the truth-functional semantics for conditionals (see above). So, the conditional premise is true, but the conjunctive conclusion is false, and hence the inference is invalid in all normal modal logics. The aim of the three experiments to which we now turn was to determine whether naïve individuals accept paraphrases, such as the one illustrated above, that follow from the model theory.

\section{Experiment 1: Epistemic and deontic conditionals, factual and counterfactual}

Our first experiment tested the prediction that the meanings of factual and counterfactual conditionals relate systematically to one another, whether they are epistemic or deontic, and whether their then clauses refer to possibilities or to certainties for epistemic conditionals and to permissions or to obligations for deontic conditionals. Each of the conditionals concerned specific events and had an if clause, a parenthetical clause, and a then clause. The if clauses were in the present tense but contained adverbials making clear that reference was being made to an event in the future (e.g., "If he gets a ticket tomorrow"). For factual conditionals, the parenthetical clause was an explicit assertion of its possibility: "which he can do"; and for counterfactual conditionals, it was an explicit assertion that it was not possible: "which he can't do." The then clauses were prefaced with "then," and for epistemic conditionals asserted either a possibility: "he may attend the ceremony" or else a certainty: "he will attend the ceremony" (and for counterfactuals, the subjunctive equivalents: "he might attend the ceremony" or "he would attend the ceremony," respectively). The then clauses for deontic conditionals asserted either a permission: "he can attend the ceremony," or else an obligation: "he must attend the ceremony" (and for counterfactuals, "he could attend the ceremony" or "he must attend the ceremony," respectively). Table 1 illustrates the eight different sorts of conditionals in the Spanish that was used in the experiment, and in English translations.

The participants' task was to select from sets of four paraphrases the one with the same meaning as each conditional. A typical trial with an epistemic conditional and its four paraphrases was "If he gets a ticket tomorrow, which he can do, then he may attend the ceremony."

i. It is possible, and remains so, that he gets a ticket tomorrow, and in that case possible that he attends the ceremony.

ii. It was once possible, but does not remain so, that he gets a ticket tomorrow, and in that case possible that he attends the ceremony. 
Table 1. Examples of epistemic and deontic factual and counterfactual conditionals with possible and certain then clauses for epistemics, and permissions and obligations for deontics

\begin{tabular}{|c|c|c|c|}
\hline & & Factual conditionals & Counterfactual conditionals \\
\hline \multirow[t]{2}{*}{ Epistemic } & Possible then clause & $\begin{array}{l}\text { Si él consigue una entrada mañana, lo cual } \\
\text { puede hacer, entonces él puede que vaya } \\
\text { a la ceremonia. } \\
\text { If he gets a ticket tomorrow, which he can do, } \\
\text { then he may attend the ceremony. }\end{array}$ & $\begin{array}{l}\text { Si él consiguiese una entrada mañana, } \\
\text { lo cual no puede hacer, entonces él } \\
\text { podría ir a la ceremonia. } \\
\text { If he were to get a ticket tomorrow, which } \\
\text { he can't do, then he might attend } \\
\text { the ceremony. }\end{array}$ \\
\hline & Certain then clause & $\begin{array}{l}\text { Si él consigue una entrada mañana, lo cual } \\
\text { puede hacer, entonces él irá a la ceremonia. } \\
\text { If he gets a ticket tomorrow, which he can do, } \\
\text { then he will attend the ceremony. }\end{array}$ & $\begin{array}{l}\text { Si él consiguiese una entrada mañana, } \\
\text { lo cual no puede hacer, entonces él } \\
\text { iría a la ceremonia. } \\
\text { If he were to get a ticket tomorrow, which } \\
\text { he can't do, then he would attend the } \\
\text { ceremony. }\end{array}$ \\
\hline \multirow[t]{2}{*}{ Deontic } & Permissive then clause & $\begin{array}{l}\text { Si tú consigues una entrada mañana, lo cual } \\
\text { puede hacer, entonces tú puedes ir a la } \\
\text { ceremonia. } \\
\text { If you get a ticket tomorrow, which you can } \\
\text { do, then you can attend the ceremony. }\end{array}$ & $\begin{array}{l}\text { Si tú consiguieses una entrada mañana, lo } \\
\text { cual no puede hacer, entonces tú podrías } \\
\text { ir a la ceremonia. } \\
\text { If you were to get a ticket tomorrow, which } \\
\text { you can't do, then you could attend the } \\
\text { ceremony. }\end{array}$ \\
\hline & Obligatory then clause & $\begin{array}{l}\text { Si tú consigues una entrada mañana, } \\
\text { lo cual puede hacer, entonces tú debes ir a la ceremonia. } \\
\text { If you get a ticket tomorrow, which you } \\
\text { can do, then you must attend the } \\
\text { ceremony. }\end{array}$ & $\begin{array}{l}\text { Si tú consiguieras una entrada mañana, lo } \\
\text { cual no puede hacer, entonces tú tienes } \\
\text { que ir a la ceremonia. } \\
\text { If you were to get a ticket tomorrow, which } \\
\text { you can't do, then you must attend the ceremony. }\end{array}$ \\
\hline
\end{tabular}

iii. It is possible, and remains so, that he gets a ticket tomorrow, and in that case certain that he attends the ceremony.

iv. It was once possible, but does not remain so, that he gets a ticket tomorrow, and in that case certain that he attends the ceremony.

The conditional in this example is factual rather than counterfactual, and so the theory predicts that the first clause of the paraphrase should be "It is possible, and remains so, that he gets a ticket tomorrow." The conditional's then clause refers to a possibility rather than to a certainty, and so it predicts that the second clause of the paraphrase should be "and in that case, possible that he attends the ceremony." So, participants should tend to select paraphrase (i) for this conditional. The prediction for counterfactual conditionals is that individuals should choose a paraphrase in which the first clause refers to a counterfactual possibility, such as "It was once possible, but does not remain so, that he gets a ticket tomorrow," and so participants should tend to select paraphrase (ii).

A typical trial with a deontic conditional was "If you get a ticket tomorrow, which you can do, then you must attend the ceremony."

i. It is possible, and remains so, that you get a ticket tomorrow, and in that case permissible for you to attend the ceremony. ii. It was once possible, but does not remain so, that you get a ticket tomorrow, and in that case permissible for you to attend the ceremony.

iii. It is possible, and remains so, that you get a ticket tomorrow, and in that case obligatory for you to attend the ceremony.

iv. It was once possible, but does not remain so, that you get a ticket tomorrow, and in that case obligatory for you to attend the ceremony.

The conditional in this example is factual rather than counterfactual, and so the first clause of the paraphrase should be "It is possible, and remains so, that you get a ticket tomorrow." The conditional's then clause refers to an obligation rather than a permission, and so the second clause of the paraphrase should be "and in that case obligatory for you to attend the ceremony." So, the theory predicts that participants will tend to select paraphrase (iii) for this conditional, and paraphrase (iv) for the counterfactual conditional with a then clause referring to an obligation.

\section{Method}

\section{Participants}

$\mathrm{G}^{*}$ Power showed that to achieve $90 \%$ power for a medium effect size with alpha $<.05$ for two-tailed tests, it was necessary to have a sample size of 47 participants in each of our 
experiments. The 48 participants in Experiment 1 were undergraduates at the University of La Laguna, Tenerife, Spain, and they were native speakers of Spanish. None of them had any training in logic nor had they taken part in any similar experiment. There were 38 women and 10 men, and their average age was 21 years, ranging from 18 to 28 years. As in all the present experiments, the participants gave their informed consent, and we report all of our manipulations and measures. They received 5 euros (around US\$5.50) for carrying out the experiment.

\section{Design and materials}

Participants acted as their own controls and carried out three trials with each of the eight sorts of conditionals, which differed in whether they were factual or counterfactual, epistemic or deontic, and referred to a possibility (a permission) or a certainty (an obligation) in their then clauses. All the materials were in Spanish. Each conditional referred to a specific future event, using such adverbials as, in English, "tomorrow," "next week," "next month," or "next year." The 24 trials were presented in a different random order to each participant.

The epistemic conditionals referred to an individual ("he" or "she"). But, to bring out the deontic interpretation, the deontic ones referred to "you." The participants' task was to select the best of four putative paraphrases. Those for epistemic conditionals had then clauses referring to possibilities or certainties, and those for deontic conditionals had then clauses referring to permissions or obligations. The order of the paraphrases was rotated so that there were four different orders for each participant, and these assignments differed in four ways over the participants. The if clauses were in the present tense with future adverbials, the parenthetical clauses were in the present tense, and the then clauses were in the present tense and in either the indicative or subjunctive mood. The clauses were in the indicative mood for factual conditionals and in the subjunctive mood for counterfactual conditionals.

The sets of paraphrases in Spanish were as follows. In each pair, the first example had a main clause referring to a possibility (or a permission), and the second example had a main clause referring to a certainty (or an obligation):

i. Factual first clause with a main clause referring to a possibility and then a permission:

Es posible, y sigue siendo así, que mañana él consigue una entrada y en ese posible caso que él asista a la ceremonia.
Es posible, y sigue siendo así, que mañana tú consigues una entrada y en ese permisible caso que tú asistas a la ceremonia.

ii. Counterfactual first clause with a main clause referring to a possibility and then a permission:

Fue posible, pero ya no sigue siendo así, que mañana él consigue una entrada y en ese posible caso que él asista a la ceremonia.

Fue posible, pero ya no sigue siendo así, que mañana tú consigues una entrada y en ese permisible caso que tú asistas a la ceremonia.

iii. Factual first clause with a main clause referring to a certainty and then an obligation:

Es posible, y sigue siendo así, que mañana él consigue una entrada y en ese seguro caso que él asista a la ceremonia.

Es posible, y sigue siendo así, que mañana tú consigues una entrada y en ese obligatorio caso que tú asistas a la ceremonia.

iv. Counterfactual first clause with a main clause referring to a certainty and then an obligation:

Fue posible, pero ya no sigue siendo así, que mañana él consigue una entrada y en ese seguro caso que él asista a la ceremonia.

Fue posible, pero ya no sigue siendo así, que mañana tú consigues una entrada y en ese obligatorio caso que tú asistas a la ceremonia.

Appendix A presents the set of 24 different conditional items used in the experiment. They were assigned in eight different ways to the eight sorts of conditionals to ensure that each item occurred equally often with each of them.

\section{Procedure}

Participants were tested in small groups of about five participants. They each received a booklet containing the instructions, which included two examples, but with no feedback of their predicted paraphrases, followed by 24 pages with a problem on each page. The instructions are presented in full in Appendix B. The participants were told that each conditional occurred with four options, and the key instruction was: "Your task is to select the option that according to you has the same meaning as the conditional assertion." They had to work on each item in the order in which it appeared in the booklet and not change any selected paraphrase once they had made a selection. 


\section{Results and discussion}

The data for this and subsequent experiments are available online at the Open Science Framework (https://osf.io/fzjgu/). Table 2 presents the percentages (in boldface) of the participants' selected paraphrases for each of the eight sorts of conditionals. They occurred with a high frequency: 46 out of the 48 participants selected more predicted paraphrases than not, and the two exceptions were ties (binomial test, $p<1$ billion). The participants selected the predicted paraphrases reliably for each of the eight sorts of conditionals (percentages ranged from $69 \%$ to $96 \%$ in Table 2, and Wilcoxon tests yielded zs ranging from 3.23 to 6.59 , with $r$ s ranging from .33 to .67 , with $p<.002$, or less, in all cases, with a Bonferroni-corrected alpha of $p<.006$ for eight comparisons; see Appendix E for details). Hence, in general, the interpretations of the conditionals concurred with the model theory.

\section{Experiment 2: Past and future conditionals, factual and counterfactual}

Experiment 1 showed that the meanings of epistemic and deontic conditionals run in parallel, and so we examined deontic conditionals no further. However, all the conditionals in that experiment referred to future events, and so Experiment 2 compared them with those referring to past events. It tested paraphrases for epistemic conditionals, and whether the parallel in meanings held for both past events and future events, and for both sorts of then clauses, possible and certain. Table 3 presents English examples of the eight sorts of conditionals in the experiment.

\section{Method}

\section{Participants}

The 48 participants in Experiment 2 were a new sample from the same undergraduate population as in Experiment 1. None had any training in logic nor had they taken part in any similar experiment. There were 42 women and six men with an average age of 19 years, ranging from 18 to 25 years. In both this and the subsequent experiment, participants received course credit for their participation.

\section{Design, materials, and procedure}

Participants acted as their own controls and carried out three trials with each of the eight sorts of epistemic conditionals, which were factual or counterfactual, referred to a possibility or a certainty in the past or in the future (as indicated in the tense of the Spanish verbs and the use of adverbs such as "yesterday," "tomorrow," and so on). The materials were 
Table 3 Examples of English past and future factual and counterfactual conditionals with possible and certain then clauses

\begin{tabular}{|c|c|c|c|}
\hline & & Factual conditionals & Counterfactual conditionals \\
\hline \multirow[t]{2}{*}{$\begin{array}{l}\text { Past } \\
\text { events }\end{array}$} & Possible then clause & $\begin{array}{l}\text { If he spoke Italian yesterday, which he } \\
\text { could have done, then he may have } \\
\text { done the interview. }\end{array}$ & $\begin{array}{l}\text { If she had owned a car last year, which } \\
\text { she didn't, then she might have met } \\
\text { the guest at the airport. }\end{array}$ \\
\hline & Certain then clause & $\begin{array}{l}\text { If he left the country last month, which } \\
\text { he could have done, then he had } \\
\text { a passport. }\end{array}$ & $\begin{array}{l}\text { If she had felt ill last week, which she } \\
\text { didn't, then she would have gone home. }\end{array}$ \\
\hline \multirow[t]{2}{*}{ Future events } & Possible then clause & $\begin{array}{l}\text { If he gets a ticket tomorrow, which } \\
\text { he can do, then he may attend } \\
\text { the ceremony. }\end{array}$ & $\begin{array}{l}\text { If she were to be overworked next year, } \\
\text { which she can't be, then she might } \\
\text { take a holiday. }\end{array}$ \\
\hline & Certain then clause & $\begin{array}{l}\text { If he is injured next month, which he } \\
\text { can be, then he will take a medical } \\
\text { leave. }\end{array}$ & $\begin{array}{l}\text { If she were employed by the firm next } \\
\text { week, which she can't be, then she would } \\
\text { attend the lunch. }\end{array}$ \\
\hline
\end{tabular}

slightly different from those in Experiment 1 . The if clauses were either in the past tense with past adverbials or in present tense with future adverbials, and they were either in the indicative or subjunctive mood. The parenthetical clauses were in the past tense and in English translation were, for example, "which he can" (lo que pudo haber sucedido) for factual conditionals, and "which he can't" (lo que no le sucedió) for counterfactual conditionals. The then clauses were either in the past tense or the future tense, depending on the tense of the if clauses. Otherwise, the design and procedure were similar to those in Experiment 1. Appendix C shows the conditionals in English and Spanish concerning past events; the conditionals concerning future events were the same as those in Experiment 1.

\section{Results}

Table 4 presents the percentages of the selected paraphrases for each of the eight sorts of conditionals. The participants chose the predicted paraphrases more often than not: 39 out of 48 participants selected more predicted paraphrases than not, seven selected more unpredicted paraphrases than not, and the remaining two were ties (binomial test, $p<$ $.000001)$. The participants selected predicted paraphrases reliably for each of the eight sorts of conditional (percentages ranged from $72 \%$ to $86 \%$ in Table 5 , and Wilcoxon tests yielded $z$ s ranging from 3.87 to $5.88, r$ s ranging from .39 to $.60, p<.0001$, or less, in all cases, with a Bonferronicorrected alpha of $p<.006$ for eight comparisons; see Appendix E for these and other tests). No reliable differences in percentages of predicted responses occurred between factual $(78 \%)$ and counterfactual conditionals $(74 \%)$, between past $(74 \%)$ and future conditionals $(77 \%)$, or between conditionals referring to possibilities $(78 \%)$ and certainties $(74 \%$; all three Wilcoxon tests yielded $z \mathrm{~s}<1.5 ; n s)$. Hence, in general, the interpretations of the past and future conditionals ran in parallel.

\section{Experiment 3: Factual, prefactual, and counterfactual interpretations}

As we remarked in the Introduction, a conditional in the subjunctive mood, such as "If he were to get a ticket tomorrow, then he might attend the ceremony" is open to two main interpretations (Johnson-Laird \& Byrne, 2002, p. 653). In one, its prefactual interpretation leaves open the possibility to which its if clause refers - he may get a ticket tomorrow. In the other, its counterfactual interpretation occurs when its if clause refers to a situation that was once possible, but is not so any longer-he can't get a ticket tomorrow. So far, we have established systematic relations between factual and counterfactual conditionals. The aim of the present study is different. Prefactual conditionals in the subjunctive mood, such as "If he were to get a ticket tomorrow, which he can do, then he might attend the ceremony," should have the same interpretation as factual conditionals in the indicative mood. With a then clause referring to a possibility, both should tend to elicit paraphrases of the following sort: "It is possible, and remains so, that he gets a ticket tomorrow, and in that case possible that he attends the ceremony." Likewise, with a then clause referring to a certainty, both should tend to elicit paraphrases of the following sort: "It is possible, and remains so, that he gets a ticket tomorrow, and in that case certain that he attends the ceremony." In contrast, counterfactual conditionals in the subjunctive mood, such as "If he were to get a ticket tomorrow, which he can't do, then he might attend the ceremony," should elicit different paraphrases in which the first clause refers to a counterfactual possibility: "It was once possible, but does not remain so, that he gets a ticket tomorrow, and in that case possible that he attends the ceremony."

We considered introducing counterfactual conditionals in the indicative mood - that is, with parenthetical clauses indicating that their if clauses were false, as in "If he gets a ticket tomorrow, which he can't do." But they seemed likely to confuse participants, because a false if clause seems to call 
for a subjunctive mood to convey that it is counterfactual. So, we did not use such indicatives in the experiment. Table 5 illustrates the six sorts of conditionals in the experiment, using the same English contents in translation from the Spanish. The model theory predicts the same interpretations for factual indicatives and prefactual subjunctives, which should contrast with counterfactual subjunctives.

\section{Method}

\section{Participants}

The 48 participants in the experiment were a new sample from the same undergraduate population as in the previous experiments. None of them had any training in logic nor had they taken part in any similar experiment. There were 36 women and 12 men with an average age of 20 years, ranging from 17 to 58 years.

\section{Design, materials, and procedure}

Participants acted as their own controls and carried out four trials with each of the six sorts of epistemic conditionals referring to future events. They were either indicative or subjunctive, and the subjunctive conditionals had either prefactual or counterfactual interpretations. Otherwise, the design, materials, and procedure were the same as those in the previous experiment. Appendix D presents the conditionals used in the experiment in Spanish and with an English translation.

\section{Results}

Table 6 presents the percentages of the participants' selected paraphrases for each of the six sorts of conditionals. They chose the predicted paraphrases much more often than not: 43 out of the 48 participants selected more predicted paraphrases, four selected more unpredicted paraphrases, and one was a tie (binomial test, $p<.00000001$ ). The participants selected predicted paraphrases reliably for each of the six sorts of conditionals (percentages ranged from $68 \%$ to $88 \%$ in Table 7, Wilcoxon tests had $z \mathrm{~s}$ ranging from 2.81 to $5.58, r \mathrm{~s}$ ranging from .29 to .57 , and $p<.005$ in all cases, with a Bonferroni-corrected alpha of $p<.008$ for six comparisons; see Appendix E).

As Table 6 shows, participants tended to make identical selections of paraphrases for indicative factual conditionals and for subjunctive prefactual conditionals, but the frequencies with which they selected these paraphrases did differ reliably $(86 \%$ and $76 \%$, respectively; Wilcoxon test, $z=$ $2.88, p<.005, r=.29$ ). Why this difference occurred is unclear, but we will offer a putative explanation below. The factual conditionals also elicited more predicted paraphrases 
Table 5 Illustrations of the six sorts of conditional in Experiment 3 (translated from the Spanish): indicative factual conditionals, subjunctive conditionals with a prefactual interpretation, and subjunctive conditionals with a counterfactual interpretation

\begin{tabular}{|c|c|c|}
\hline & Indicative factuals & Subjunctive prefactuals \\
\hline $\begin{array}{l}\text { Possible then } \\
\text { clauses }\end{array}$ & $\begin{array}{l}\text { If he gets a ticket tomorrow, which } \\
\text { he can do, then he may attend } \\
\text { the ceremony. }\end{array}$ & $\begin{array}{l}\text { If he were to get a ticket tomorrow, which } \\
\text { he can do, then he might attend the } \\
\text { ceremony. }\end{array}$ \\
\hline \multirow[t]{2}{*}{$\begin{array}{l}\text { Certain then } \\
\text { clauses }\end{array}$} & $\begin{array}{l}\text { If he gets a ticket tomorrow, which } \\
\text { he can do, then he will attend } \\
\text { the ceremony. }\end{array}$ & $\begin{array}{l}\text { If he were to get a ticket tomorrow, } \\
\text { which he can do, then he would } \\
\text { attend the ceremony. }\end{array}$ \\
\hline & & Subjunctive counterfactuals \\
\hline Possible then clauses & & $\begin{array}{l}\text { If he were to get a ticket tomorrow, which } \\
\text { he can't do, then he might attend } \\
\text { the ceremony. }\end{array}$ \\
\hline Certain then clauses & & $\begin{array}{l}\text { If he were to get a ticket tomorrow, which he } \\
\text { can't do, then he would attend the ceremony. }\end{array}$ \\
\hline
\end{tabular}

Note. Each occurred with possible and with certain then clauses

than did counterfactual conditionals $(86 \%$ vs. $72 \%$; Wilcoxon's test, $z=3.94, p<.001, r=.40$ ). The relative difficulty of counterfactuals follows from the model theory. They have two explicit mental models: one represents the counterfactual possibility to which their if clause and then clause refer, and the other represents the facts of the matter (Johnson-Laird \& Byrne, 2002, p. 657). So, they impose a larger load on working memory than factuals and should therefore tend to be slightly harder to interpret.

\section{General discussion}

Naïve participants tended to select paraphrases of various sorts of conditionals according to the model theory's predictions. Given a factual conditional such as the following (translated from the Spanish in our experiments): "If she is overworked next year, which she can be, then she will take a holiday," the participants' preferred paraphrase was "It is possible, and remains so, that she is overworked next year, and in that case certain that she takes a holiday." And, given its counterfactual analog, "If she were overworked next year, which she can't be, then she would take a holiday," their preferred paraphrase was "It was once possible, but does not remain so, that she is overworked next year, and in that case certain that she takes a holiday." They selected these paraphrases and analogous ones for deontic conditionals about permissions or obligations (in Experiment 1). The same pattern of selected paraphrases occurred for epistemic assertions both about past events and future events (Experiment 2).

Table 6. Percentages of selections of the four paraphrases in Experiment $3(N=48)$ for factual conditionals, prefactual conditionals, and counterfactual conditionals, with clauses referring to possibilities or certainties

Factual conditionals:

If $A$ occurred, which it can, then $C$.
Prefactual conditionals:

If $A$ had occurred, which it can, then $C$

\begin{tabular}{|c|c|c|c|c|c|c|c|c|}
\hline & \multicolumn{4}{|l|}{ Sort of paraphrases } & \multicolumn{4}{|l|}{ Sort of paraphrases } \\
\hline & $\begin{array}{l}\text { Possible A possible } \\
\quad \text { C }\end{array}$ & $\begin{array}{l}\text { Possible } \\
\text { A } \\
\text { certain C }\end{array}$ & $\begin{array}{l}\text { Once possible } \\
\text { A } \\
\text { possible C }\end{array}$ & $\begin{array}{l}\text { Once possible } \\
\text { A } \\
\text { certain } \mathrm{C}\end{array}$ & $\begin{array}{l}\text { Possible A possible } \\
\quad \text { C }\end{array}$ & $\begin{array}{l}\text { Possible } \\
\text { A } \\
\text { certain C }\end{array}$ & $\begin{array}{l}\text { Once } \\
\text { possible } \\
\text { A } \\
\text { possible } \\
\text { C }\end{array}$ & $\begin{array}{l}\text { Once } \\
\text { possible } \\
\quad \text { A } \\
\text { certain C }\end{array}$ \\
\hline $\begin{array}{l}\text { Possible then } \\
\text { clause }\end{array}$ & 88 & 10 & 2 & 0 & 81 & 17 & 2 & 0 \\
\hline \multirow[t]{2}{*}{ Certain then clause } & 15 & 84 & 1 & 1 & 27 & 70 & 2 & 1 \\
\hline & & & & & \multicolumn{4}{|c|}{$\begin{array}{l}\text { Counterfactual conditionals: } \\
\text { If } A \text { had occurred, which it can't, then } C \text {. }\end{array}$} \\
\hline $\begin{array}{l}\text { Possible } \\
\text { then clause }\end{array}$ & & & & & 3 & 3 & 76 & 18 \\
\hline Certain then clause & & & & & 3 & 3 & 26 & 68 \\
\hline
\end{tabular}

Note. The percentages of predicted paraphrases are in boldface 
Subjunctive conditionals can be used to express counterfactual possibilities (as in the preceding example), but they also have a prefactual interpretation that leaves open the occurrence of the event in their if clause, as in "If she were overworked next year, which she can be, then she would take a holiday." The participants' preferred paraphrases for prefactual conditionals were identical to their preferred ones for their factual equivalents, whereas their preferred paraphrases for subjunctives expressing counterfactual possibilities corroborated the previous study (Experiment 3). These results are consistent with the patterns of inference from factual and prefactual conditionals (Byrne \& Egan, 2004). So, overall, the results bore out the model theory's account of the parallel meanings of conditionals.

Of course, variations and divagations occurred in the experimental results, but none challenged the theory. For example, factual conditionals tended to yield more predicted paraphrases than their prefactual counterparts in the subjunctive mood (Experiment 3). One possible reason for this small but reliable difference is that the subjunctive mood may intimate that there's an alternative to the facts, and thereby lead some participants to envisage two possibilities, one in which the if clause holds ("she is overworked next year") and another in which it does not ("she is not overworked next year"). This additional load on working memory could reduce the proportion of predicted paraphrases. Counterfactuals should be harder than factuals because counterfactuals call for two explicit mental models whereas factuals need only one. The difference also has consequences for different sorts of deductions from them (e.g., Byrne \& Tasso, 1999; Johnson-Laird \& Byrne, 2002).

The meanings of conditionals, according to the model theory, are rooted in finite models of alternative outcomes (Johnson-Laird \& Ragni, 2019). So, a simple factual conditional of the sort If $A$, then $C$ refers to a conjunction of possibilities that each hold in default of information to the contrary. The first and most salient possibility, which is represented in the one mental model with explicit content, is the default possibility in which both clauses hold. The conditional's if clause establishes that it is possible that $A$, which presupposes that it is possible that not $A$. It follows that conditionals refer to a conjunction of three default possibilities, which are exhaustive:

It is possible that $\mathrm{A}$ and that $\mathrm{C}$.

It is possible that not $\mathrm{A}$ and that not $\mathrm{C}$.

It is possible that not $\mathrm{A}$ and that $\mathrm{C}$.

When individuals have to list what is possible given a factual conditional, nearly everyone, children and adults alike, list the first of the three possibilities, and as the capacity of children's working memory increases they tend to list the other two possibilities in the order shown above (e.g., Barrouillet, Grosset, \& Lecas, 2000). Individuals also judge that the corresponding assertions, such as $A$ and $C$, could be jointly true with the conditional (Goodwin \& Johnson-Laird, 2018). These default possibilities imply the predicted paraphrases of the conditionals in our experiments. Inferences yielding the default possibilities seem obvious, but, as we showed in the account of theories of the conditional, they are invalid in all normal modal logics.

We outlined four main theories of the meanings of conditionals in the earlier section on the topic - the model theory, which motivated the predictions for the present studies, and three rival accounts, which we now consider in the light of the results of our experiments. The truth-functional theory treats the meaning of conditionals as a function from the respective truth values of their two clauses to the truth value of the conditional as a whole. This interpretation is in orthodox logic and in some psychological theories based on formal rules of inference (e.g., Braine \& O'Brien, 1991). It fails to account for our results in two ways. First, it has nothing to say about counterfactual conditionals, which cannot have truth-functional meanings, because their if clauses are false by definition, but some of these conditionals are true, and some of them are false. Second, the paraphrases that individuals accept are invalid in normal modal logics, because, as we pointed out earlier, they embody the truth-functional interpretation of conditionals.

One defense of truth-functional meanings suggests an alternative to the model theory. Grice (1989) argued that assertions can mean more than they say, because of the conventions governing discourse. One convention, he claimed, is that speakers who assert a conditional do not believe that its if clause is false. So, when speakers assert, say "If it is raining, then it is hot," the following condition holds:

\section{Speakers do not believe that it is false that it is raining.}

There is then a conversational implicature that the conditional's if clause is true (i.e., it is true that it is raining). Granted this implicature, the meaning of the conditional is truth functional (see the section Theories of the Meanings of Conditionals). By definition, implicatures are not valid deductions, because they can be canceled without contradiction. For example, suppose a speaker precedes the conditional above with the remark "It is good that it isn't raining." It follows that the speaker does not believe the if clause of the conditional to be true, because it asserts that it is raining, and so the implicature is canceled without contradiction. The conditional's if clause is false, it is truth functional, and therefore it is true. Hence, a meteorological prediction is true merely because the speaker asserts that its if clause is false. This consequence is absurd. It is known as the "paradox" of the material conditional, which Grice has aimed to avoid. 
Yet a Gricean explanation of the three default possibilities to which a conditional refers might still seem to be feasible (cf. Sauerland, 2004). Gricean implicatures of the three default possibilities for the meteorological conditional above would call for two conditions:

2. Speakers do not believe that it is impossible that it is raining.

3. Speakers do not believe that is impossible that it is not raining.

The implicature from (2) is that it is possible that it is raining, and the implicature from (3) is that it is possible that it is not raining. They and the meaning of the conditional yield the three default possibilities:

It is possible that it is raining and that it is hot, and it is possible that it is not raining and that it is not hot, and it is possible that it is not raining and that it is hot.

Alas, this account of the Gricean origin of the three default possibilities has a crucial defect. From the clause in (2) that it is impossible that it is raining, it follows in all normal modal logics that it is false that it is raining. So, (2) implies:

Speakers do not believe that it is false that it is raining.

This condition is identical to (1) - the condition that Grice invoked for the implicature:

It is true that it is raining.

So, (2) and (3) implicate truths. That is too strong because, as we showed above, speakers assert conditionals when they know that their if clauses are false. In sum, a Gricean approach explains the origin of the three default possibilities, but only at the cost of implying a blatant falsity.

A possible-worlds semantics fails to predict our results. Lewis (1973) argued that the meanings of factual and counterfactual conditionals do not run in parallel, and so his account cannot accommodate our results. Stalnaker (1968), however, adopted a uniform approach to both sorts of conditional. In principle, it might be able to predict our results, but it is not a realistic psychological proposal. On its account, a conditional is true provided that in a possible world in which its if clause holds and that differs minimally from the actual world its then clause also holds. So, where you believe its if clause, your evaluation of the conditional is the same as your evaluation of its then clause in the possible world corresponding to your beliefs. But, where you believe its if clause to be false, you need to carry out an additional initial step. You need to modify your stock of beliefs to accommodate the if clause by making minimal changes to your beliefs. This account is not feasible for how individuals understand conditionals. On the one hand, consider the test for whether an if clause is consistent with your beliefs: If you have $N$ beliefs pertinent to the if clause, and each belief can be modified to be false if necessary, then there are $2^{N}$ modifications to check to ensure that at least in one combination of truth values they can all be true together with the if clause. This problem is computationally intractable (see Cook, 1971; e.g., if $N$ equals 10 , you have to check more than a thousand combinations). Moreover, each possible world relevant to an if clause fixes whether an assertion about the world under discussion is true or false: So, each possible world must be vast, and a vast number of them has to exist. They are too big and too numerous, as Partee (1979) pointed out, to fit inside anyone's mind.

Probabilistic theories are of several sorts (e.g., Elqayam \& Over, 2013; Evans, 2012; Fugard et al., 2011; Lucas \& Kemp, 2015; Oaksford \& Chater, 2007; Over \& Cruz, 2017). Some of them take the meaning of a conditional to be the conditional probability of its then clause given its if clause. On this account, truth values of conditionals are at best "ersatz" (Adams, 1998), and the validity of inferences from them has to be replaced with probabilistic validity in which the probability of a conclusion cannot be less than the probability of the premises. Yet, on the contrary, people are happy to judge conditionals and other compounds to be true or false, and to judge that certain conclusions are true given a conditional premise. And when they judge inferences to be valid in this way, their judgments of the probabilities of premises and conclusions often violate probabilistic validity (e.g., Hinterecker, Knauff, \& Johnson-Laird, 2016).

A crucial problem for all the probabilistic theories is that they have nothing to say about possibilities, and so they cannot make predictions about the paraphrases in our experiments. They are in particular trouble with deontic assertions, which have no paraphrases in terms of probabilities. A museum attendant tells you, for example, "If you have a ticket for noon, then you must enter in the next 5 minutes." This speech act creates a conditional obligation for you. It cannot be expressed, however, in a statement of a pure probability (Johnson-Laird \& Ragni, 2019). So, the assertion "If you have a ticket for noon, then the probability of your entering in the next 5 minutes is $100 \%$ " does not obligate you to enter. Indeed, you may decide not to enter despite your obligation, and so the first conditional remains true, but the second conditional is false. Likewise, the following paraphrase that participants (in Experiment 1) tended to accept for certain deontic conditionals: "It is possible, and remains so, that you get a ticket tomorrow, and in that case obligatory for you to attend the ceremony" cannot be expressed as a probability. It is certainly not a probability of $100 \%$, because people do not always fulfill their obligations. So, probabilistic theories cannot account for the present results. Their most serious problem, however, is the presumption that naïve individuals know how to estimate the probabilities of compound assertions. They do 
not; and they often make gross errors (Khemlani, Lotstein, \& Johnson-Laird, 2015). When they estimate the probability of each possible contingency given a conditional, the sum of their estimates is highly subadditive (i.e., well over $100 \%$, contrary to probabilistic theories; Byrne \& Johnson-Laird, 2019).

In conclusion, an indicative conditional, such as "If he is injured tomorrow, then he will take some leave" has a factual paraphrase: "It is possible, and remains so, that he is injured tomorrow, and in that case, it is certain that he takes some leave." Subjunctive conditionals, such as "If he were injured tomorrow, which he can be, then he would take some leave" have a prefactual interpretation with the same paraphrase. But, when context shows that the if clause refers to a counterfactual possibility, it has a corresponding paraphrase: "It was once possible, but does not remain so, that he was injured." Our experiments corroborated these predictions. Apt paraphrases of conditionals of various sorts support the model theory rather than its current alternatives.

Author note The data for this article are archived at the OSF (https://osf.io/fzjgu/). The research was supported by a grant (PSI2015-70771-P) from the Spanish Ministry of Science and Innovation (Ministerio de Ciencia e Innovación). We thank friends and colleagues for advice: Geoff Goodwin, Sunny Khemlani, Juan Madruga, Cristina Quelhas, Marco Ragni, Carlos Santamaría, Alessandra Tasso, Alicia BolañosMedina, and the late Vittorio Girotto.

\section{Appendix A: Materials for Experiment 1}

The 24 content items used in Experiment 1 in one assignment to the eight sorts of conditionals. The English translation is provided first, and then the original Spanish.

1. Epistemic, factual conditionals, with possible then clauses

If he gets a ticket tomorrow, which he can do, then he may attend the ceremony.

If she buys chocolate after lunch next week, which she can do, then she may bring money to school.

If he hires a car next month, which he can do, then he may have a license.

Si él consigue una entrada mañana, lo cual puede hacer, entonces él puede que vaya a la ceremonia

Si ella compra chocolate después del almuerzo la próxima semana, lo cual puede hacer, entonces ella puede que traiga dinero a la escuela.

Si él alquila un coche el próximo mes, lo cual puede hacer, entonces él puede que tenga una licencia.

2. Epistemic, counterfactual conditionals, with possible then clauses
If she were to be overworked next year, which she can't be, then she might take a holiday.

If he were to book a hotel suite tomorrow, which he can't do, then he might check out early.

If she were to vote in the election next week, which she can't do, then she might be registered in the census.

Si ella estuviera sobrecargada de trabajo el próximo año, que no puede estar, entonces ella podría tomarse unas vacaciones.

Si él tuviera que reservar una suite de hotel mañana, lo cual no puede hacer, entonces él podría salir temprano del hotel.

Si ella votase en las elecciones la próxima semana, lo cual no puede hacer, entonces ella podría estar inscrita en el censo.

3. Epistemic, factual conditionals, with certain then clauses

If he is injured next month, which he can be, then he will take a medical leave.

If she checks in online for her flight next year, which she can do, then she will go directly to security.

If he goes to the ball tomorrow, which he can do, then he will have a suit.

Si él está lesionado el próximo mes, que puede estar, entonces él cogerá una baja médica.

Si ella hace el check-in en internet para su vuelo el próximo año, lo cual puede hacer, entonces ella irá directamente a seguridad.

Si él va al baile de etiqueta mañana, lo cual puede hacer, entonces él llevará un esmoquin.

4. Epistemic, counterfactual conditionals, with certain then clauses

If she were employed by the firm next week, which she can't be, then she would attend the

lunch.

If he were to enter the library next month, which he can't $d o$, then he would have an ID card.

If she were to lose weight next year, which she can't do, then she would go to the gym.

Si ella estuviera empleada por la empresa la próxima semana, que no puede estar, entonces ella asistiría al almuerzo.

Si él tuviera que entrar en la biblioteca el próximo mes, lo cual no puede hacer, entonces él tendría el DNI.

Si ella fuera a perder peso el próximo año, lo cual no puede hacer, entonces ella iría al gimnasio.

5. Deontic, factual conditionals, with permissible then clauses 
If you speak Italian tomorrow, which you can do, then you can do the interview.

If you have an urgent message next week, which you can have, then you can send the e-mail.

If you are very hungry next month, which you can be, then you can eat something.

Si tú hablas italiano mañana, lo cual puedes hacer, entonces tú puedes hacer la entrevista.

Si tú tienes un mensaje urgente la próxima semana, que puedes tener, entonces tú puedes enviar el e-mail.

Si tú tienes mucha hambre el próximo mes, que puedes tener, entonces tú puedes comer algo.

6. Deontic, counterfactual conditionals, with permissible then clauses

If you were to own a car next year, which you can't do, then you could meet the guest at the airport.

If you were to order a burger tomorrow, which you can't do, then you could have chips.

If you were to be cold next week, which you can't be, then you could put on your coat.

Si tú tuvieras un coche el próximo año, que no puedes tener, entonces tú podrías recibir al invitado en el aeropuerto.

Si tú pidieras una hamburguesa mañana, lo cual no puedes hacer, entonces tú

podrías comer papas fritas.

Si tú tuvieras frío la próxima semana, que no puedes tener, entonces tú podrías ponerte el abrigo.

7. Deontic, factual conditions, with obligatory then clauses

If you leave the country next month, which you can do, then you must have a passport.

If you board the train next year, which you can do, then you must have a ticket.

If you have a bike tomorrow, which you can have, then you must take part in the race.

Si tú abandonas el país el próximo mes, lo cual puedes hacer, entonces tú debes tener un pasaporte.

Si tú subes al tren el próximo año, lo cual puedes hacer, entonces tú debes tener el billete.

Si tú tienes una bicicleta mañana, que puedes tener, entonces tú debes participar en la carrera.

8. Deontic, counterfactual conditionals, with obligatory then clauses

If you were to feel ill next week, which you can't do, then you must go home.

If you were to attend the private clinic next month, which you can't do, then you must have health insurance.
If you were to work as a psychologist next year, which you can't do, then you must have a degree in psychology.

Si estuvieras enferma/o la próxima semana, que no puedes estar, entonces tú tienes que irte a casa.

Si tú fueses a la clínica privada el próximo mes, lo cual no puedes hacer, entonces tú tienes que tener un seguro médico.

Si tú fueras a trabajar como psicóloga/o el próximo año, lo cual no puedes hacer, entonces tú tienes que tener un título en psicología.

\section{Appendix B: The complete instructions for Experiment 1 (translated from the Spanish)}

This experiment is not a test of your intelligence or personality. We are interested in how people in general understand various sorts of conditional assertions, such as: "If the sun is shining, then it is hot." In this experiment, we will present you with a conditional assertion with four options. Your task is to select the option that, according to you, has the same meaning as the conditional assertion. Please, put a cross (X) over the selected option. Now, here are two examples:

Example 1:

If she has sore skin tomorrow, which she can have, then she may put protective cream on.

i. It is possible, and remains so, that she has sore skin tomorrow, and in that case possible that she put protective cream on.

ii. It was once possible, but does not remain so, that she has sore skin tomorrow, and in that case possible that she put protective cream on.

iii. It is possible, and remains so, that she has sore skin tomorrow, and in that case certain that she put protective cream on.

iv. It was once possible, but does not remain so, that she has sore skin tomorrow, and in that case certain that she put protective cream on.

Please select the option that has the same meaning as the conditional assertion.

Example 2:

If you know the thief next week, which you can do, then you must inform the police.

i. It is possible, and remains so, that you know the thief next week, and in that case permissible for you to inform the police.

ii. It was once possible, but does not remain so, that you know the thief next week, and in that case permissible for you to inform the police.

iii. It is possible, and remains so, that you know the thief next week, and in that case obligatory for you to inform the police.

iv. It was once possible, but does not remain so, that you know the thief next week, and in that case obligatory for you to inform the police. 
Please select the option that has the same meaning that the conditional assertion.

You should work on just one problem at a time. Once you have completed a problem, you cannot go back and change your answer. You can work on the problems at your own pace. If you have any questions during this experiment, please let us know, and we will help you.

Your participation in this experiment is voluntary and anonymous (names or ID are not required), and once the data in the booklets have been recorded, they will be destroyed. Finally, please do not discuss this experiment with your peers, because they may be acting as participants in the near future. Once we have analyzed the results, however, we will give you a full debriefing on the point of the experiment. Thank for your participation.

\section{Appendix C: Materials for Experiment 2}

The materials were identical to those in Experiment 1 for the first four conditions. Here are examples of the conditionals in the past tense:

1. Past tense, factual conditionals, with possible then clauses

If he spoke Italian yesterday, which he could have done, then he may have done the interview.

If she had an urgent message last week, which she could have had, then she may have sent the e-mail.

If he was very hungry last month, which he could have been, then he may have eaten something.

Si él hablo italiano ayer, lo que pudo haber sucedido, entonces él puedes que haya hecho la entrevista.

Si ella tuvo un mensaje urgente la semana pasada, lo que pudo haber sucedido, entonces ella puede que haya enviado el e-mail.

Si él tuvo mucha hambre el mes pasado, lo que pudo haber sucedido, entonces él puede que haya comido algo.

2. Past tense, counterfactual conditionals, with possible then clauses

If she had owned a car last year, which she didn't, then she might have met the guest at the airport.

If he had ordered a burger yesterday, which he didn't, then he might have had chips.

If she had been cold last week, which she wasn't, then she might have put on her coat.

Si ella hubiera tenido un coche el año pasado, lo que no le sucedió, entonces ella podría haber recibido al invitado en el aeropuerto.

Si él hubiera pedido una hamburguesa ayer, lo que no le sucedió, entonces él podría haber comido papas fritas.

Si ella hubiera tenido frío la semana pasada, lo que no le sucedió, entonces ella podría haberse puesto el abrigo.
3. Past tense, factual conditionals, with certain then clauses

If he left the country last month, which he could have done, then he had a passport.

If she boarded the train last year, which she could have done, then she had a ticket.

If he had a bike yesterday, which he could have had, then he took part in the race.

Si él abandono el país el mes pasado, lo que pudo haber sucedido, entonces él tuvo un pasaporte.

Si ella subió al tren el año pasado, lo que pudo haber sucedido, entonces ella tuvo el billete.

Si él tuvo una bicicleta ayer, lo que pudo haber sucedido, entonces él participo en la carrera.

4. Past tense, counterfactual conditionals, with certain then clauses

If she had felt ill last week, which she didn't, then she would have gone home.

If he had had health insurance last month, which he didn't, then he would have attended the private clinic.

If she had had a degree in psychology last year, which she didn't, then she would have worked as a psychologist.

Si ella se hubiera sentido enferma la semana pasada, lo que no le sucedió, entonces ella se habría ido a casa.

Si él hubiese ido a la clínica privada el mes pasado, lo que no le sucedió, entonces él tendría un seguro médico.

Si ella hubiera ido a trabajar como psicóloga el año pasado, lo que no le sucedió, entonces ella tendría un título en psicología.

\section{Appendix D: Materials for Experiment 3}

1. Factual conditionals with possible then clauses

If he gets a ticket tomorrow, which he can do, then he may attend the ceremony.

If she buys chocolate after lunch next week, which she can do, then she may bring money to school.

If he hires a car next month, which he can do, then he may have a license.

If she is overworked next year, which she can be, then she may take a holiday.

Si él consigue una entrada mañana, lo que es posible, entonces él puede que vaya a la ceremonia

Si ella compra chocolate después del almuerzo la próxima semana, lo que es posible, entonces ella puede que traiga dinero a la escuela.

Si él alquila un coche el próximo mes, lo que es posible, entonces él puede que tenga una licencia.

Si ella está sobrecargada de trabajo el próximo año, lo que es posible, entonces ella puede que se tome unas vacaciones. 
2. Prefactual conditionals with possible then clauses

If he were to order a burger tomorrow, which he can do, then he might have chips.

If she were to be cold next week, which she can be, then she might put on your coat.

If he were to leave the country next month, which he can do, then he might have a passport.

If she were to board the train next year, which she can do, then she might have a ticket.

Si él tuviera que reservar una suite de hotel mañana, lo que es posible, entonces él podría salir temprano del hotel.

Si ella votase en las elecciones la próxima semana, lo que es posible, entonces ella podría estar inscrita en el censo.

Si él estuviese lesionado el próximo mes, lo que es posible, entonces él podría cogerse una baja médica.

Si ella hiciese el check-in en internet para su vuelo el próximo año, lo que es posible, entonces ella podría ir directamente a seguridad.

3. Counterfactual conditionals with possible then clauses

If he were to book a hotel suite tomorrow, which he can't do, then he might check out early.

If she were to vote in the election next week, which she can't do, then she might be registered in the census.

If he were to be injured next month, which he can't be, then he might take a medical leave.

If she were to check in online for her flight next year, which she can't do, then she might go directly to security.

Si él va al baile de etiqueta mañana, lo que no es posible, entonces él llevará un esmoquin.

Si ella es empleada de la empresa la próxima semana, lo que no es posible, entonces ella asistirá al almuerzo.

Si él tiene que entrar en la biblioteca el próximo mes, lo que no es posible, entonces él tendrá el DNI.

Si ella va a perder peso el próximo año, lo que no es posible, entonces ella irá al gimnasio.

4. Factual conditionals with certain then clauses

If he goes to the ball tomorrow, which he can do, then he will have a suit.

If she is employed by the firm next week, which she can be, then she will attend the lunch.

If he enters the library next month, which he can do, then he will have an ID card.

If she lost weight next year, which she can do, then she will go to the gym.

Si él hablase italiano mañana, lo que es posible, entonces él haria la entrevista.

Si ella tuviese un mensaje urgente la próxima semana, lo que es posible, entonces ella enviaría el e-mail.
Si él tuviese mucha hambre el próximo mes, lo que es posible, entonces él comería algo.

Si ella tuviera un coche el próximo año, lo que es posible, entonces ella recibiría al invitado en el aeropuerto.

5. Prefactual conditionals with certain then clauses

If he were to have a bike tomorrow, which he can have, then he would take part in the race.

If she were to feel ill next week, which she can do, then she would go home.

If he were to attend the private clinic next month, which he can do, then he would have health insurance.

If she were to work as a psychologist next year, which she can do, then she would have a degree in psychology.

Si él pidiera una hamburguesa mañana, lo que es posible, entonces él podría comer papas fritas.

Si ella tuviera frío la próxima semana, lo que es posible, entonces ella podría ponerse el abrigo.

Si él abandonase el país el próximo mes, lo que es posible, entonces él podría tener un pasaporte.

Si ella subiese al tren el próximo año, lo que es posible, entonces ella podría tener el billete.

6. Counterfactual conditionals with certain then clauses

If he were to speak Italian tomorrow, which he can't do, then he would do the interview.

If she were to have an urgent message next week, which she can't have, then she would send the e-mail.

If he were to be very hungry next month, which he can't be, then he would eat something.

If she were to own a car next year, which she can't do, then she would meet the guest at the airport.

Si él tuviese una bicicleta mañana, lo que no es posible, entonces él participaría en la carrera.

Si ella se sintiera enferma la próxima semana, lo que no es posible, entonces ella se iría a casa.

Si él fuese a la clínica privada el próximo mes, lo que no es posible, entonces él tendría un seguro médico.

Si ella fuera a trabajar como psicóloga el próximo año, lo que no es posible, entonces ella tendría un título en psicología.

\section{Appendix E: Summary of the Wilcoxon tests for Experiments 1 - 3}

Experiment 1 Wilcoxon tests of predicted versus unpredicted selections of paraphrases for epistemic and deontic factual and counterfactual conditionals (see Table 2).

\section{Epistemic:}

Factual conditionals with possible then clauses, $92 \%$ vs. $8 \%, z=6.31, p<.001, r=.64$ 
Counterfactual conditionals with possible then clauses, $88 \%$ vs. $12 \%, z=5.87, p<.001, r=.60$

Factual conditionals with certain then clauses, $90 \%$ vs. $10 \%, z=6.27, p<.001, r=.64$

Counterfactual conditionals with certain then clauses, $69 \%$ vs. $31 \%, z=3.23, p<.002, r=.33$

\section{Deontic:}

Factual conditionals with permissible then clauses, $96 \%$ vs. $4 \%, z=6.59, p<.001, r=.67$

Counterfactual conditionals with permissible then clauses, $90 \%$ vs. $10 \%, z=6.16, p<.001, r=.63$

Factual conditionals with obligatory then clauses, $94 \%$ vs. $6 \%, z=6.47, p<.001, r=.66$

Counterfactual conditionals with obligatory then clauses, $88 \%$ vs. $12 \% ; z=6.03, p<.001, r=.62$

Experiment 2 Wilcoxon tests of predicted versus unpredicted selections of paraphrases for past and future factual and counterfactual conditionals (see Table 4).

\section{Past conditionals:}

Factual conditionals with possible then clauses, $76 \%$ vs. $24 \%, z=4.54, p<.001, r=.46$

Counterfactual conditionals with possible then clauses, $78 \%$ vs. $22 \%, z=4.93, p<.001, r=.50$

Factual conditionals with certain then clauses, $72 \%$ vs. $28 \%, z=4.18, p<.001, r=.43$

Counterfactual conditionals with certain then clauses, $72 \%$ vs. $28 \%, z=3.91, p<.001, r=.40$

\section{Future conditionals:}

Factual conditionals with possible then clauses, $86 \%$ vs. $14 \%, z=5.88, p<.001, r=.60$

Counterfactual conditionals with possible then clauses, $72 \%$ vs. $28 \%, z=3.87, p<.001, r=.39$

Factual conditionals with certain then clauses, $76 \%$ vs. $24 \%, z=4.67, p<.001, r=.48$

Counterfactual conditionals with certain then clauses, $74 \%$ vs. $26 \%, z=4.38, p<.002, r=.45$

Experiment 3: Wilcoxon tests of predicted versus unpredicted selections of paraphrases for factual, prefactual, and counterfactual conditionals (see Table 6).

Factual conditionals with possible then clauses, $88 \%$ vs. $12 \% ; z=5.58, p<.001, r=.57$

Factual conditionals with certain then clauses, $84 \%$ vs. $16 \% ; z=4.79, p<.001, r=.49$

Prefactual conditionals with possible then clause, $81 \%$ vs. $19 \% ; z=5.08, p<.001, r=.52$

Prefactual conditionals with certain then clauses, $70 \%$ vs. $30 \% ; z=4.93, p<.002, r=.50$

Counterfactual conditionals with possible then clauses, $76 \%$ vs. $24 \% ; z=5.43, p<.001, r=.55$

Counterfactuals conditionals with certain then clauses, $68 \%$ vs. $32 \% ; z=2.81, p<.006, r=.29$

\section{References}

Adams, E. W. (1975). The logic of conditionals: An application of probability to deductive logic. Dordrecht, Netherlands: Reidel.

Adams, E. W. (1998). A primer of probability logic. Stanford, CA: Center for the Study of Language and Information.

Barrouillet, P., Grosset, N., \& Lecas, J.-F. (2000). Conditional reasoning by mental models: Chronometric and developmental evidence. Cognition, 75, 237-266.

Braine, M. D., \& O'Brien, D. P. (1991). A theory of if: A lexical entry, reasoning program, and pragmatic principles. Psychological Review, 98(2), 182-203. doi:https://doi.org/10.1037/0033295X. 98.2.182

Byrne, R. M. J. (2005). The rational imagination: How people create alternatives to reality. Cambridge, MA: MIT Press.

Byrne, R. M. J. (2016). Counterfactual thought. Annual Review of Psychology, 67, 135-157.

Byrne, R. M. J., \& Egan, S. M. (2004). Counterfactual and prefactual conditionals. Canadian Journal of Experimental Psychology/Revue canadienne de psychologie expérimentale, 58, 113-120.

Byrne, R. M. J., \& Johnson-Laird, P. N. (2019). If and or: Real and counterfactual possibilities in their truth and probability. Journal of Experimental Psychology: Learning, Memory, and Cognition, 46(4), 760-780. doi:https://doi.org/10.1037/xlm0000756

Byrne, R. M. J., \& Tasso, A. (1999). Deductive reasoning with factual, possible, and counterfactual conditionals. Memory \& Cognition, 27, 726-740.

Cook, S. A. (1971). The complexity of theorem-proving procedures. Proceedings of the Third Annual Association of Computing Machinery Symposium on the Theory of Computing (pp. 151158). New York, NT: ACM. doi:https://doi.org/10.1145/800157. 805047

De Brigard, F., \& Parikh, N. (2019). Episodic counterfactual thinking. Current Directions in Psychological Science, 28, 59-66.

Elqayam, S., \& Over, D. E. (2013). New paradigm psychology of reasoning: An introduction to the special issue edited by Elqayam, Bonnefon, and Over. Thinking \& Reasoning, 19, 249-265.

Espino, O., \& Byrne, R. M. J. (2018). Thinking about the opposite of what is said: Counterfactual conditionals and symbolic or alternate simulations of negation. Cognitive Science, 42, 2459-2501. doi: https://doi.org/10.1111/cogs.12677

Espino, O., Santamaría, C., \& Byrne, R. M. J. (2009). People think about what is true for conditionals, not what is false: Only true possibilities prime the comprehension of "if". Quarterly Journal of Experimental Psychology, 62(6), 1072-1078. doi:https://doi.org/10.1080/ 17470210802602375

Evans, J. St. B. T. (2012). Questions and challenges for the new psychology of reasoning. Thinking \& Reasoning, 18(1), 5-31. doi:https:// doi.org/10.1080/13546783.2011.637674

Fugard, A. J. B., Pfeifer, N., Mayerhofer, B., \& Kleiter, G. (2011). How people interpret conditionals: Shifts toward the conditional event. Journal of Experimental Psychology: Learning, Memory, \& Cognition, 37, 635-648.

Girle, R. (2009). Modal logics and philosophy (2nd). London, England: Routledge.

Goodwin, G. P., \& Johnson-Laird, P. N. (2018). The truth of conditional assertions. Cognitive Science, 42, 2502-2533. doi:https://doi.org/ $10.1111 / \operatorname{cogs} .12666$

Grice, H. P. (1989). Studies in the way of words. Cambridge, MA: Harvard University Press.

Hinterecker, T., Knauff, M., \& Johnson-Laird, P. N. (2016). Modality, probability, and mental models. Journal of Experimental Psychology: Learning, Memory, and Cognition, 42, 1606-1620.

Jeffrey, R. (1981). Formal logic. New York, NY: McGraw-Hill. 
Johnson-Laird, P. N. (1983). Mental models. Cambridge, MA: Harvard University Press.

Johnson-Laird, P. N. (2006). How we reason. New York, NY: Oxford University Press.

Johnson-Laird, P. N., \& Byrne, R. M. J. (1991). Deduction. Hillsdale, NJ: Erlbaum.

Johnson-Laird, P. N., \& Byrne, R. M. J. (2002). Conditionals: A theory of meaning, pragmatics, and inference. Psychological Review, 109, 646-678.

Johnson-Laird, P. N., Khemlani, S. S., \& Goodwin, G. P. (2015). Logic, probability, and human reasoning. Trends in Cognitive Sciences, 19, 201-214. https://doi.org/10.1016/j.tics.2015.02.006

Johnson-Laird, P. N., \& Ragni, M. (2019). Possibilities as the foundation of reasoning. Cognition, 193, 130950. doi:https://doi.org/10.1016/j. cognition.2019.04.019

Khemlani, S. S., Byrne, R. M. J., \& Johnson-Laird, P. N. (2018). Facts and possibilities: A model-based theory of sentential reasoning. Cognitive Science, 1-38. Advance online publication. doi:https:// doi.org/10.1111/cogs.12634

Khemlani, S. S., Lotstein, M., \& Johnson-Laird, P. N. (2015). Naïve probability: Model-based estimates of unique events. Cognitive Science, 39, 1216-1258.

Khemlani, S. S., Mackiewicz, R., Bucciarelli, M., \& Johnson-Laird, P. N. (2013). Kinematic mental simulations in abduction and deduction. Proceedings of the National Academy of Sciences of the United States of America, 110, 16766-16771.

Kratzer, A. (2012). The notional category of modality. In A. Kratzer (Ed.), Modals and conditionals: New and revised perspectives (pp. 21-69). Oxford, England: Oxford University Press.

Lassiter, D. (2017). Graded modality: Qualitative and quantitative perspectives. New York, NY: Oxford University Press.

Lewis, D. (1973). Counterfactuals. Cambridge, MA: Harvard University Press.

Lucas, C. G., \& Kemp, C. (2015). An improved probabilistic account of counterfactual reasoning. Psychological Review, 122, 700-734.

Malle, B. F. (2018). From binary deontics to deontic continua: The nature of human (and robot) norm systems. Paper presented at the Third International Robo-Philosophy Conference, University of Vienna, Austria. Retrieved from http://research.clps.brown.edu/soccogsci/ Publications/Pubs/Malle_2018_Deontic_Continua_Vienna.pdf

Miller, G. A., \& Johnson-Laird, P. N. (1976). Language and perception. Cambridge, MA: Harvard University Press.

Moens, M., \& Steedman, M. (1988). Temporal ontology in natural language. Computational Linguistics, 2, 15-21.
Nickerson, R. (2015). Conditional reasoning. Oxford, England: Oxford University Press.

Oaksford, M., \& Chater, N. (2007). Bayesian rationality: The probabilistic approach to human reasoning. Oxford, England: Oxford University Press.

Over, D. E., \& Cruz, N. (2017). Probabilistic accounts of conditional reasoning. In V. Thompson \& L. Ball (Eds.), International handbook of thinking and reasoning (pp. 434-450). London, England: Routledge.

Partee, B. H. (1979). Semantics-Mathematics or psychology? In R. Bäuerle, U. Egli, \& A. von Stechow (Eds.), Springer Series in Language and Communication: Semantics from different points of view Vol. 6, pp. 1-13). Berlin, Germany: Springer-Verlag.

Phillips, J., Morris, A., \& Cushman, F. (2019). How we know what not to think. Trends in Cognitive Sciences, 23(12), 1026-1040. doi:https:// doi.org/10.1016/j.tics.2019.09.007

Quelhas, A. C., Johnson-Laird, P. N., \& Juhos, C. (2010). The modulation of conditional assertions and its effects on reasoning. Quarterly Journal of Experimental Psychology, 63, 1716-1739.

Quelhas, A. C., Rasga, C., \& Johnson-Laird, P. N. (2017). A priori true and false conditionals. Cognitive Science, 41, 1003-1030.

Quelhas, A. C., Rasga, C., \& Johnson-Laird, P. N. (2018). The relation between factual and counterfactual conditionals. Cognitive Science, 42, 2205-2228.

Reichenbach, H. (1956). The direction of time. Berkeley: University of California Press.

Santamaría, C., Espino, O., \& Byrne, R. M. J. (2005). Counterfactual and semifactual conditionals prime alternative possibilities. Journal of Experimental Psychology: Learning, Memory, and Cognition, 31, $1149-1154$.

Sauerland, U. (2004). Scalar implicatures in complex sentences. Linguistics and Philosophy, 27, 367-391.

Schaeken, W., Schroyens, W., \& Dieussaert, K. (2001). Conditional assertions, tense, and explicit negatives. European Journal of Cognitive Psychology, 13, 433-450.

Stalnaker, R. C. (1968). A theory of conditionals. In N. Rescher (Ed.), Studies in logical theory. Oxford, England: Basil Blackwell.

White, A. R. (1975). Modal thinking. Ithaca, NY: Cornell University Press.

Publisher's note Springer Nature remains neutral with regard to jurisdictional claims in published maps and institutional affiliations. 